\title{
Direct fluorophore conjugation to genomic DNA for microarray-based epigenomic profiling
}

\author{
Vineet Gupta, Ph.D. \\ Massachusetts General Hospital, Harvard Medical School
}

http://massgeneral.org/chemicalbiology 
Non-Enzymatic Conjugation of Fluorescent Dyes to Nucleic Acids

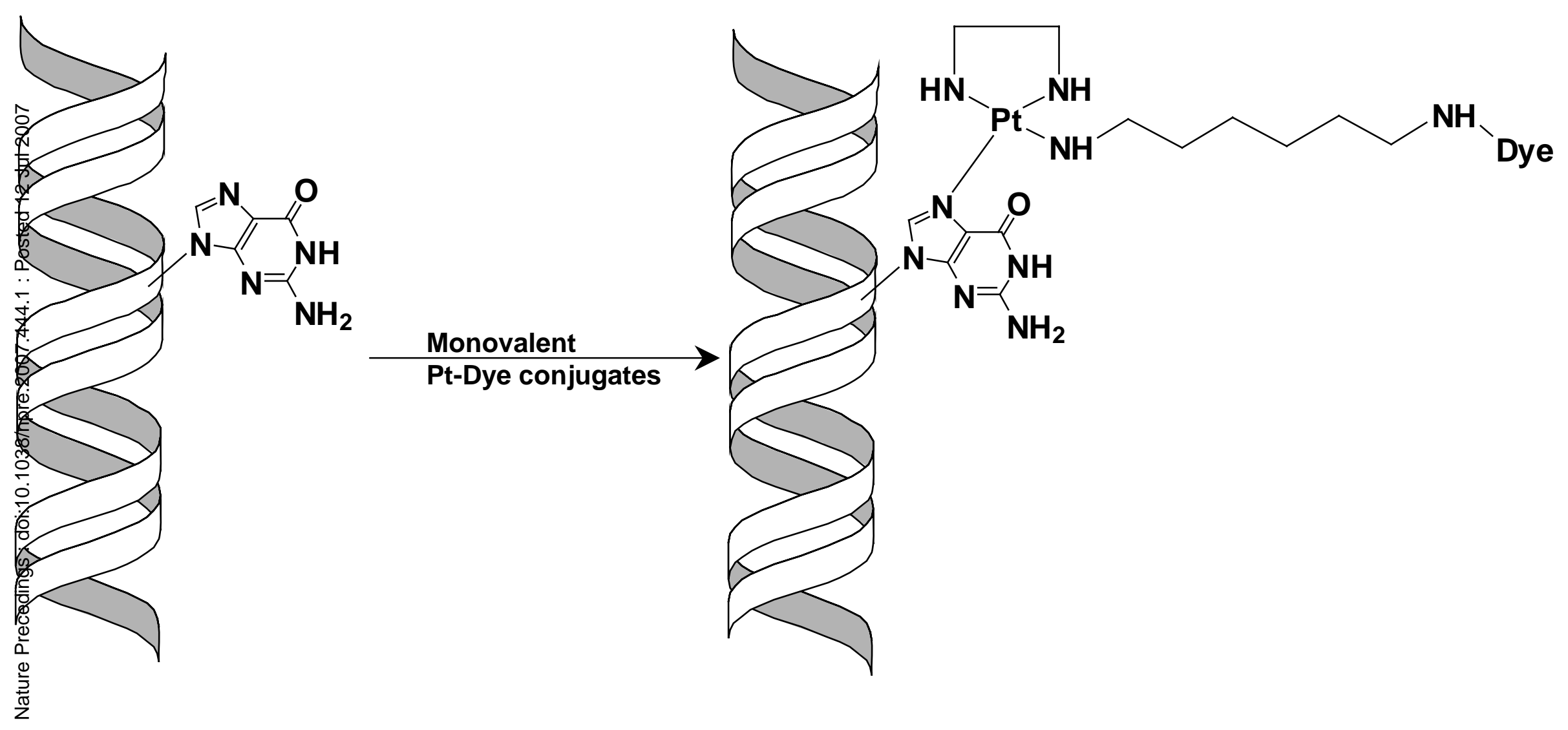

Platinum-based reagents (such as ULS from Kreatech) selectively react with and label the N7 of Guanine residues 


\section{Conjugated mRNA Produces Highly Precise Expression Profiles}

Differential gene expression profile from six replica experiments using

HL-60 mRNA (Cy3 labeled) Vs Jurkat mRNA (Cy5 labeled)

hybridized to 4800-element cDNA arrays

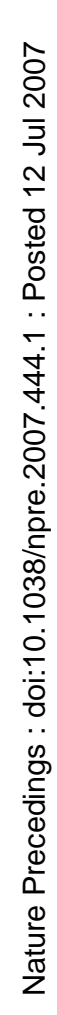

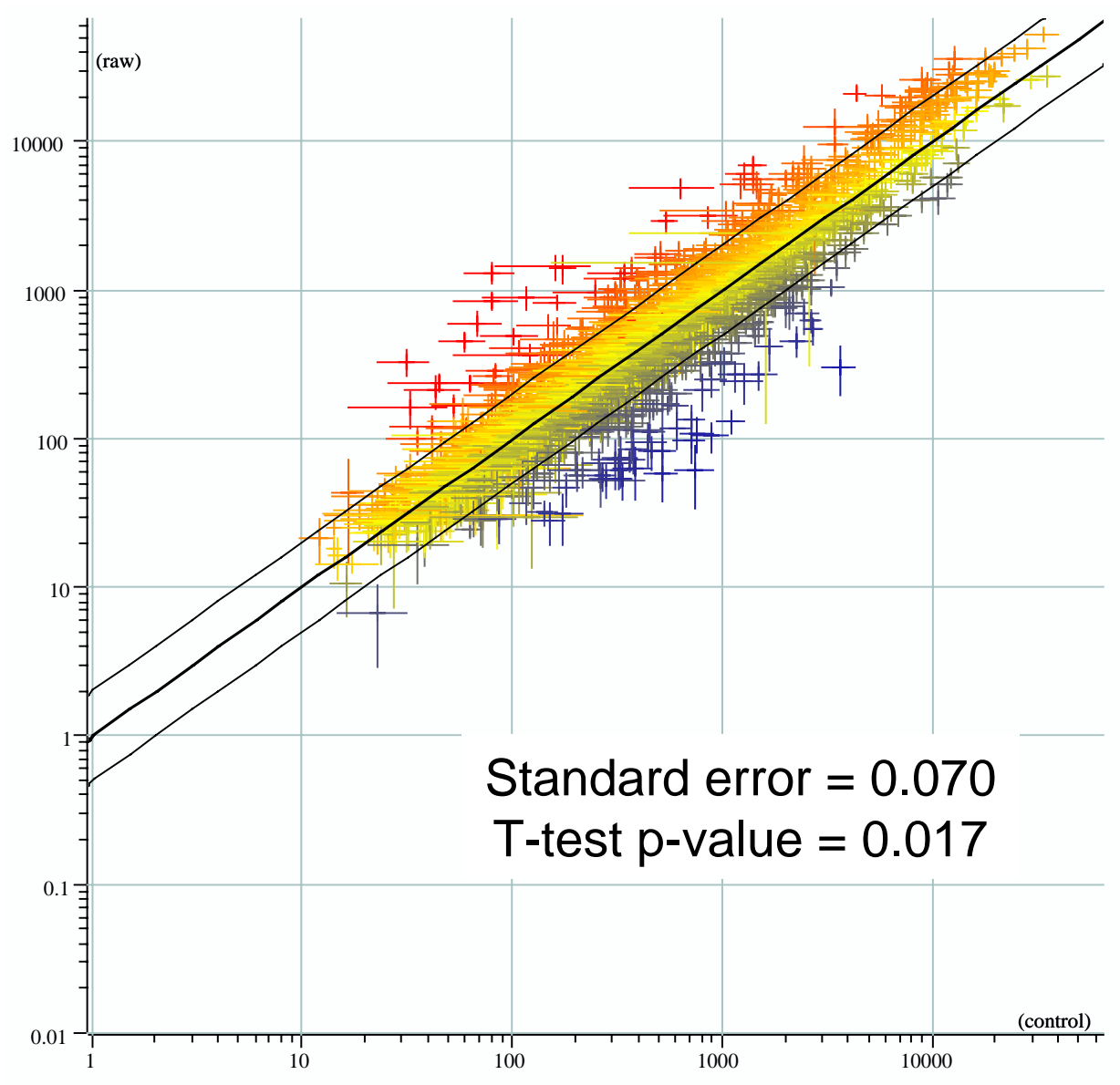

Same/Same gene expression profile from replicates

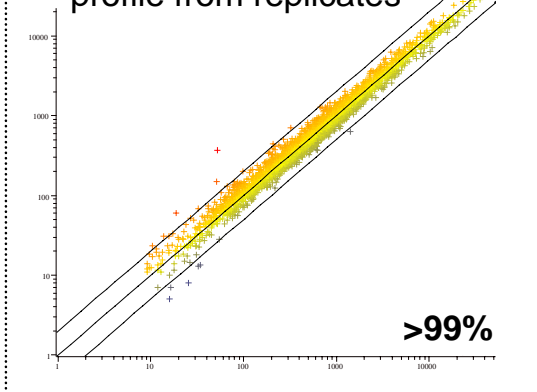

Directly labeled mRNA produces high quality microarray expression profiles 


\section{Genomic DNA Can Similarly Be Directly Fluorescently Labeled}

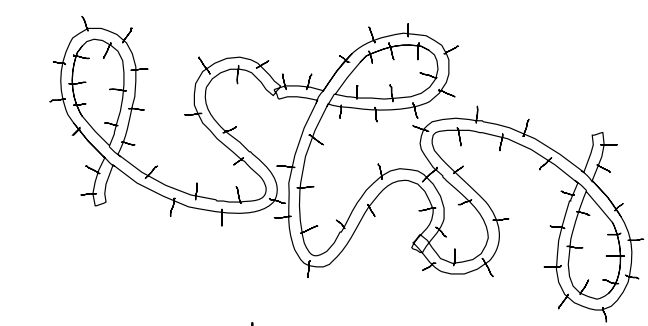

Enzymatic Fragmentation

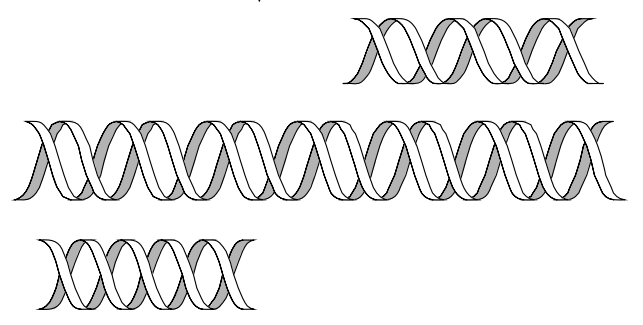

Direct Fluorescent Labeling

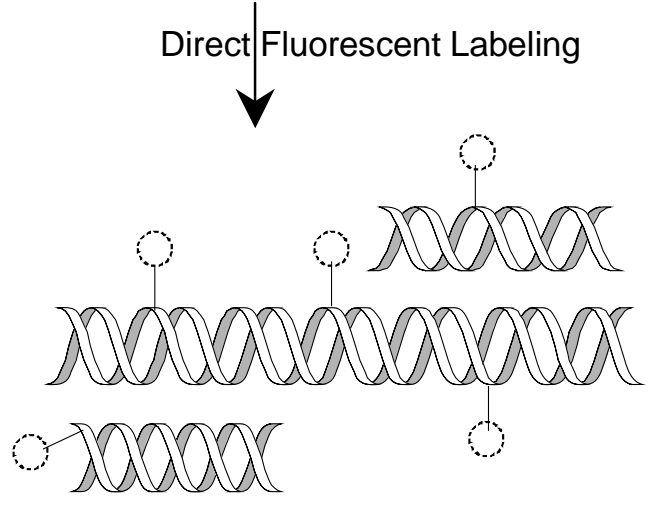

Genomic DNA (gDNA)

Fragmented gDNA

Labeled gDNA
Суз ${ }^{\mathrm{M}}$

12234
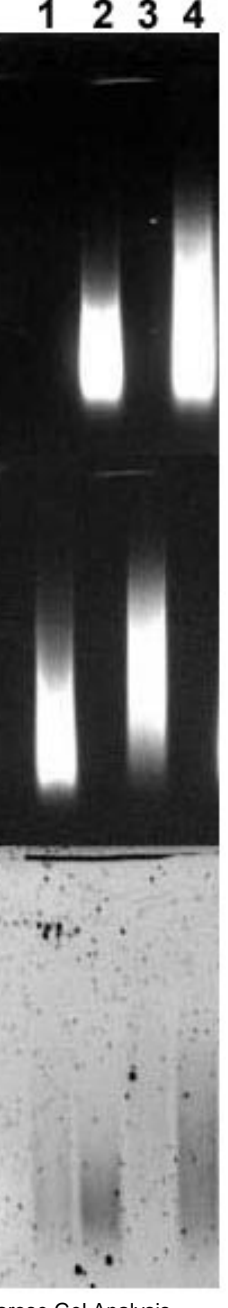

M= Aqg Lambda-HindIIII DNA Marker $1=$ Jurkat gDNA treated w/ Msel

= Jurka gDNA treated w/ Msel + McrBC $3=$ Jurkat $g$ DNA treated $w / M s p l$

$4=$ Jurkat gDNA treated $\mathrm{w} / \mathrm{Mspl}+\mathrm{McrBC}$

Genomic DNA can be differentially digested with methylation-sensitive restriction enzymes and directly fluorescently labeled 


\section{Epigenomic Profiling with Directly Labeled Genomic DNA}

Microarray-based epigenomic profiling using Jurkat gDNA and oligo arrays

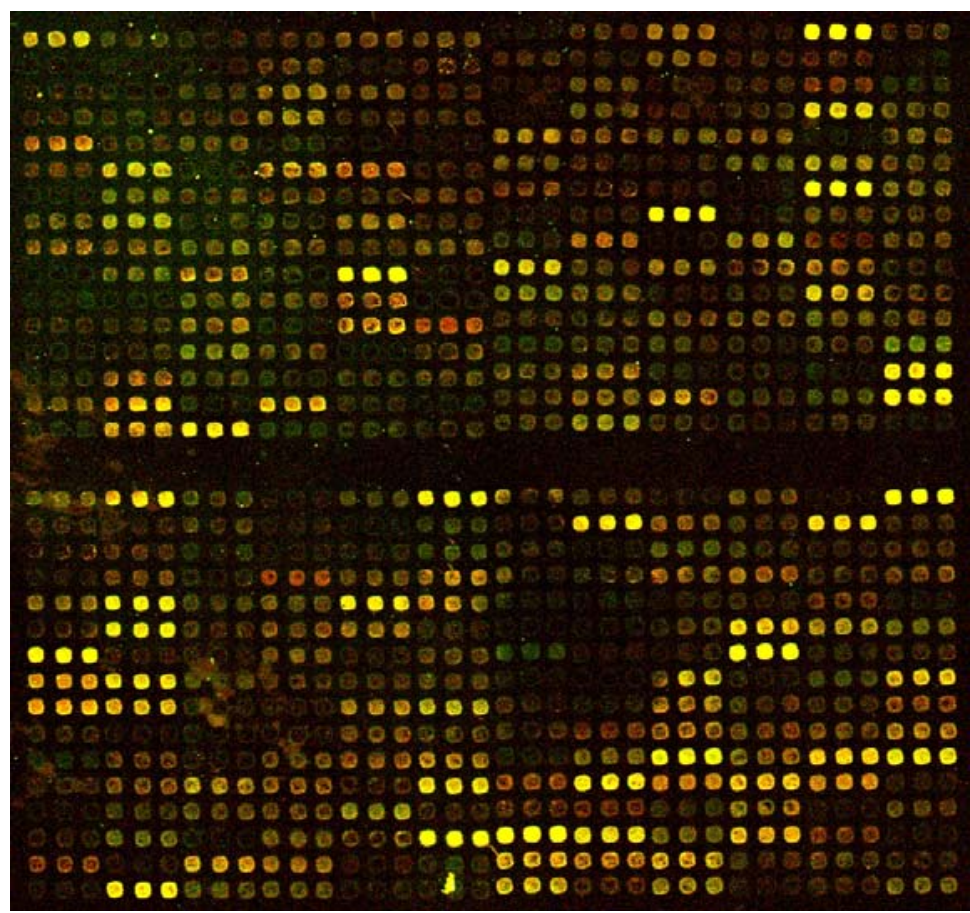

Methylation-dependent gDNA Fragmentation and Direct Labeling (MFDL) can be used for Microarray-based epigenomic profiling 


\section{Epigenomic Profiling with Directly Labeled Genomic DNA}

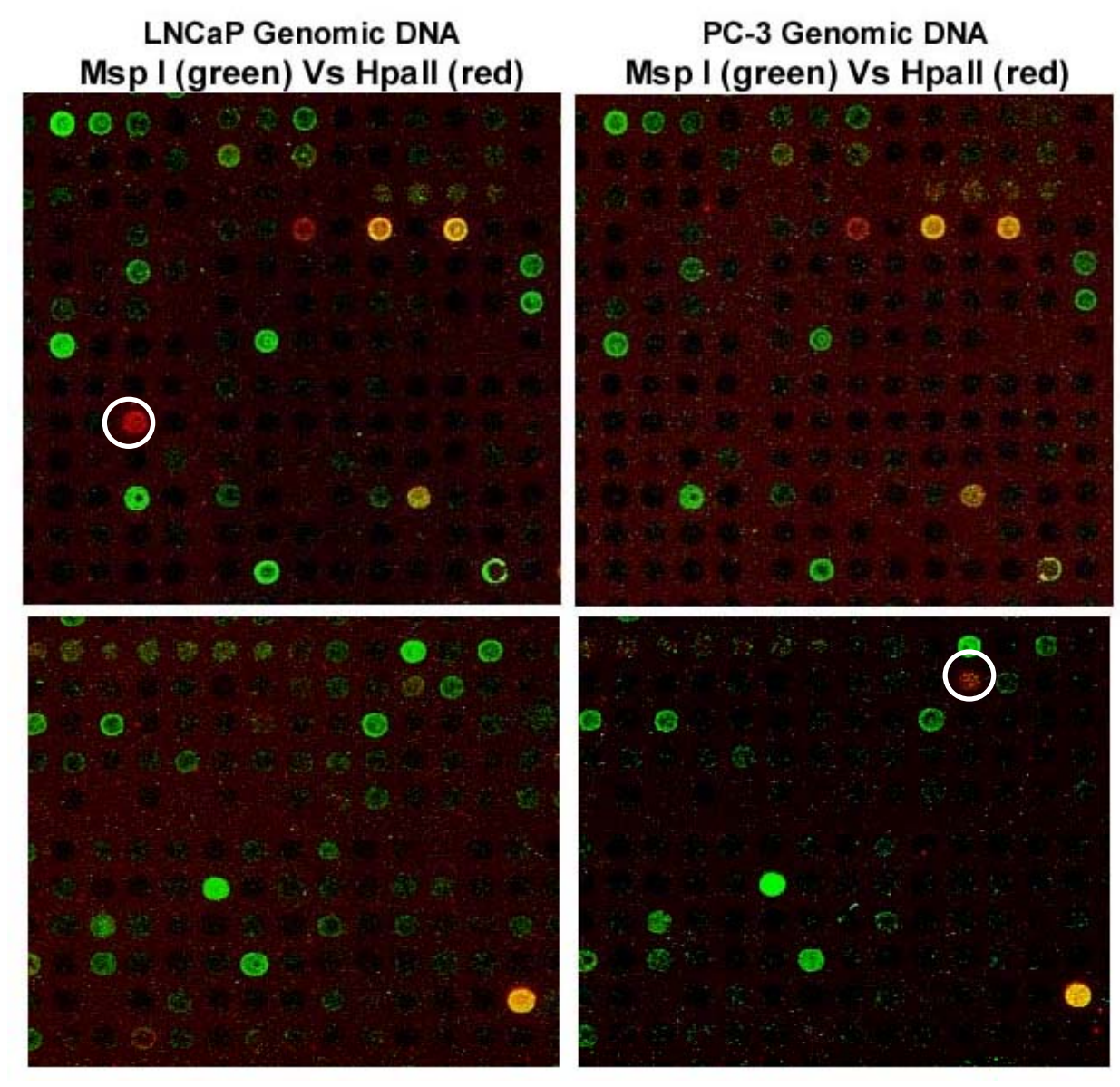

Methylation-dependent gDNA Fragmentation and Direct Labeling (MFDL) can be used for Microarray-based epigenomic profiling to identify differentially-methylated loci 


\section{Size Fractionation of gDNA by Sonication}

gDNA
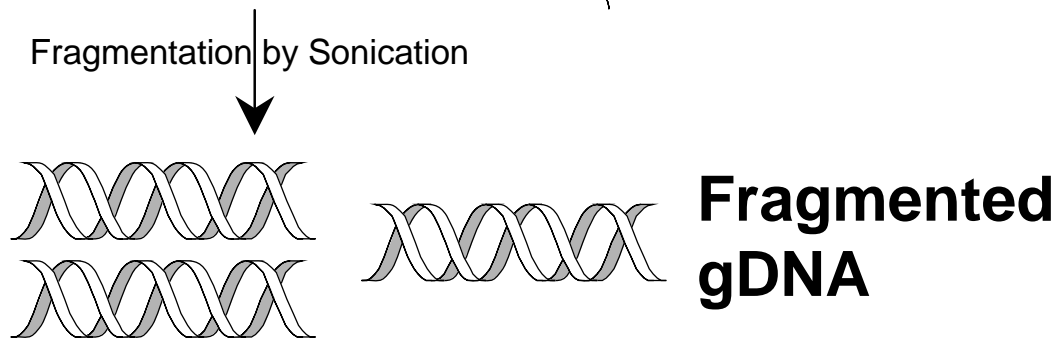

1. Adaptor Ligation

2. Differential Digestion w/ methyl-sensitive REs

3. PCR enrichment and labeling of non-digested DNA

Microarray-based

Epigenomic Profiling
Size of gDNA progressively gets smaller with increasing time of Sonication

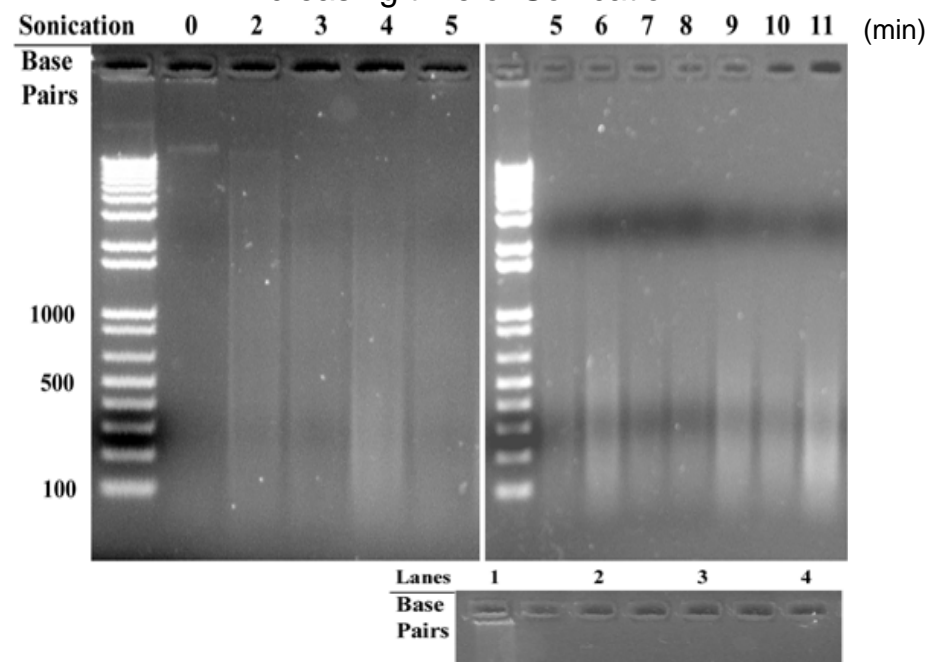

Sonicated gDNA fragments can be selectively amplified using PCR

Genomic DNA can be size-fractionated by sonication (using published protocols) prior to MFDL for epigenomic profiling 